\title{
No Miracle in Massacbusetts Why Governor Romney's Health Care Reform Won't Work
}

\author{
by Michael Tanner
}

No. 97

June 6, 2006

\section{Executive Summary}

Massachusetts has enacted one of the most far-reaching state health insurance reform packages in recent decades. Much attention has been focused on the act's unprecedented mandate that every resident obtain health insurance coverage. However, the act goes far beyond an individual mandate to radically change the way health insurance is bought and sold in the state. Many observers see Massachusetts's reforms as a model for the nation, but a closer look provides ample reasons to be skeptical. Among them:

- The individual mandate opens the door to widespread regulation of the health care industry and political interference in personal health care decisions.
- The act's subsidies are poorly targeted and overly generous.

- The Massachusetts Health Care Connector, which restructures the individual and small business insurance markets, is a form of managed competition that has the potential to severely limit consumer choice.

- The act imposes new burdens on business and creates a host of new government bureaucracies to manage the health care system.

Health care needs more consumer control and freer markets, not more government regulation, controls, and subsidies. The Massachusetts reform takes us in the wrong direction.

Michael Tanner is director of health and welfare studies at the Cato Institute and coauthor of Healthy Competition: What's Holding Back Health Care and How to Free It (2005). 


\section{The individual} mandate is an unprecedented expansion of government power and intrusion into the American health care system.

\section{Introduction}

On April 12, 2006, Massachusetts Gov. Mitt Romney signed into law one of the most far-reaching experiments in health care reform since President Bill Clinton's ill-fated attempt at national health care. The plan thrust the state-and potential presidential candidate Romney-into the forefront of the national debate over how to improve the U.S. health care system and extend coverage to the estimated 46 million uninsured people in the United States.

Among the key components of the bill are the following:

- Every Massachusetts resident will be required to have health insurance by July 2007. Those who do not receive insurance through their employers or a government plan such as Medicare will be required to purchase it on their own. ${ }^{1}$ Failure to comply with this mandate will result in the loss of the individual's personal exemption for the state income tax in 2007, and beginning in 2008 there will be a penalty equal to 50 percent of the cost of a standard insurance policy. ${ }^{2}$

- Low- and middle-income citizens who do not have employer-provided health insurance will receive subsidies to assist them in purchasing health insurance. The subsidies will be available on a sliding scale to individuals and families with incomes up to 300 percent of the federal poverty level. ${ }^{3}$

- A new entity, called the Massachusetts Health Care Connector, is created to restructure the individual and small business insurance markets. Notably, the Connector will enable individuals to use pretax dollars to purchase insurance, thereby leveling the playing field between employer-provided and individually purchased insurance. ${ }^{4}$

- Employers with more than 10 workers who fail to provide health insurance to their workers will be assessed a fee of up to
\$295 per employee. ${ }^{5}$ In addition, employers whose workers repeatedly receive uncompensated care may be subject to additional penalties. ${ }^{6}$

- Medicaid recipients will eventually be brought into the private health insurance market on a subsidized basis.

The plan has drawn praise from across the political spectrum. The conservative Heritage Foundation was instrumental in designing it and has called it "one of the most promising strategies out there." The plan has also been endorsed by such liberal luminaries as Sens. Hillary Clinton (D-NY), Edward M. Kennedy (D-MA), and John Kerry (D-MA). ${ }^{8}$

Governor Romney has said that he sees the proposal as a key element in his expected 2008 presidential run, an opportunity to steal a traditionally Democratic issue. "Issues which have long been the province of the Democratic Party to claim as their own will increasingly move to the Republican side of the aisle," Romney said in an interview with Bloomberg. ${ }^{9}$ Many longtime political observers seem to concur.

Yet, there are many reasons to be skeptical. The individual mandate is an unprecedented expansion of government power and intrusion into the American health care system. It marks the first time that an individual, simply by virtue of living in a state, has been required to purchase a specific government-defined product. On a practical level, the mandate is likely to prove unenforceable. More important, the individual mandate will almost certainly lead to a cascading series of additional mandates and regulations resulting, ultimately, in ever-greater government control of the health care system.

At the same time, the law's subsidies are both overgenerous and poorly targeted. Many of those receiving the subsidies will be people who have health insurance today. Moreover, the availability of subsidies will encourage employers to shift their costs by discontinuing insurance, thereby dumping their workers into the subsidized public system.

The law is wrong-headed at a more fundamental level as well. Governor Romney has 
gone to great pains to differentiate the Massachusetts law from the ill-fated Clinton health plan of 1993, and it certainly is less expensive, prescriptive, and regulatory. However, at their heart, both are essentially forms of managed competition. Unlike single-payer plans or national health insurance, both plans would leave the provision of health care and health insurance in private hands, but they would create an artificial marketplace run under strict government control.

Health care needs more consumer control and freer markets, not more government regulation, controls, and subsidies. We must shift the health care debate away from its single-minded focus on expanding coverage to the bigger question of how to reduce costs and improve quality. That will require the introduction of market mechanisms to give consumers more control over and responsibility for their health care decisions.

Mitt Romney's Massachusetts reform takes us in the wrong direction.

\section{The Mandate}

Perhaps the most publicized aspect of the Massachusetts reform is its mandate that every resident have health insurance, provided either by an employer or the government or purchased individually. This is, as the Congressional Budget Office has noted, an "unprecedented" level of state intervention in personal decisionmaking. It is the first time that a state has mandated that an individual, simply by virtue of living in the state, must purchase a particular state-defined product. ${ }^{10}$

This provision was designed to deal with a legitimate-if overstated-issue, uncompensated care for "free riders" on the current health care system. When an individual without health insurance becomes sick or injured, he or she still receives medical treatment. In fact, hospitals are legally required to provide care regardless of ability to pay. Physicians do not face the same legal requirement, but few are willing to deny treatment because a patient lacks insurance. However, such treat- ment is not free. The cost is simply shifted to others, those with insurance or, more often, taxpayers.

The mandate is also an attempt to "strengthen and stabilize the functioning of health insurance risk pools" within the insurance market. ${ }^{11}$ Massachusetts law mandates a modified form of community rating, which forbids insurance companies from pricing their products on the basis of age or health. That drives up the cost of insurance for the young and the healthy in order to subsidize premiums for the older and sicker. The state also mandates that insurance policies include some 40 distinct and often-costly benefits, further driving up insurance prices. As a result, many young, healthy people, unable to purchase low-cost catastrophic insurance, have made the logical decision to simply go without insurance. However, removing the young and healthy from the insurance pool means that the people remaining in the pool are older and sicker. This results in higher insurance premiums for those who are insured.

Finally, the mandate is perceived as a move toward universal coverage. Many of the law's proponents have long equated insurance coverage with access to health care and access to care with better health. Thus, while the current law falls far short of their goal of a universal single-payer system, many see an individual mandate as a move in the right direction and likely to produce better health outcomes in the long run.

At the time the bill was enacted, there were approximately 550,000 Massachusetts residents without health insurance, roughly 13.2 percent of the population under age $65 .^{12}$ This compares with about 17.8 percent nationwide. The state spends just under $\$ 1$ billion per year on uncompensated care through its uncompensated care pool. Approximately \$606 million of this is from state funds, which come from a combination of general revenues, tobacco settlement funds, and surcharges on hospitals and private insurance plans. The insurance and hospital surcharges, which average about $\$ 65$ per employee, are eventually passed on to businesses that offer health
Health care needs more consumer control and freer markets, not more government regulation, controls, and subsidies. 
insurance to their workers. An additional \$385 million comes from federal Medicaid funds that Massachusetts redirects into its uncompensated care pool. ${ }^{13}$ In fact, it was the federal government's threat not to renew the state's Medicaid waiver, thereby halting that $\$ 385$ million, that provided the impetus for the legislature to act.

Although $\$ 1$ billion seems like a great deal of money, overall health care spending in Massachusetts tops $\$ 40$ billion, making uncompensated care pool expenditures about 2.5 percent of total health care spending. ${ }^{14}$ Of course, some additional uncompensated care costs are passed along, not to taxpayers, but to private payers. But that is a relatively small amount, estimated at about 15 percent nationally. ${ }^{15}$ If those costs are added to the spending from the uncompensated care pool, total uncompensated care costs are less than 3 percent of all health care spending in Massachusetts, at the low end of the national average estimated at 3-5 percent. ${ }^{16}$ Uncompensated care, therefore, although a real problem, is a manageable one that would not appear to require this type of radical step.

Nor will the individual mandate solve the problem. Some of the act's supporters talk about its covering 85 percent of the state's uninsured within three years, bringing total insurance coverage to 99 percent of the population. In reality, that appears to be wishful thinking.

To make an individual mandate work, the state must be able to determine whether residents are insured or not and to penalize those who have not complied with the mandate. Experience suggests the state is illequipped to do either.

Governor Romney repeatedly likens the health insurance mandate to his state's mandate that all drivers have auto insurance. This is an imperfect analogy, however. First, it has long been recognized that driving is a privilege, subject to all manner of regulatory requirements. If one does not like the regulations, including an insurance mandate, one can choose not to drive. A health insurance mandate would not give people such a choice. Second, the reason states mandate auto insur- ance is for the protection of others rather than oneself. Massachusetts, like most states, does not mandate that a person carry insurance for his own injury or repair costs.

However, auto insurance does provide a useful guide to how difficult it will be to enforce the mandate. Massachusetts was the first state to require the purchase of auto liability insurance back in 1927. Proof of auto insurance is required to register a car, and driving without insurance is subject to a $\$ 500$ fine. ${ }^{17}$ Nevertheless, roughly 7 percent of all Massachusetts drivers remain uninsured. ${ }^{18}$ That is actually relatively low compared to the other 46 states that require drivers to purchase automobile liability insurance. Roughly 14.5 percent of drivers in those states are uninsured. In some states, such as Texas, the uninsured motorist rate runs as high as 18 percent. As many as 25-30 percent of Los Angeles drivers are uninsured. By comparison, in the three states without mandatory auto insurance, roughly 15 percent of drivers are uninsured. ${ }^{19}$ In fact, millions of Americans purchase "uninsured motorist" coverage to protect themselves in an accident in which the other driver is uninsured.

Under the new law, every Massachusetts taxpayer must indicate on his state tax return that he, and his dependents, had health insurance coverage during the previous year (with no lapse longer than 63 days). ${ }^{20}$ The act is silent on how the state will verify insurance coverage of those residents not required to file (incomes under $\$ 8,000$ for an individual, $\$ 14,750$ if filing jointly). Although presumably many such individuals would be covered under Medicaid, many Medicaid-eligible individuals have never enrolled in the program. After all, some of the nonfilers will be elderly, homeless, and mentally ill. And roughly 7 percent of uninsured Massachusetts residents are illegal immigrants. ${ }^{21}$ Presumably, many of those people are outside the tax system as well.

There is also the question of how the state will deal with the thousands of Massachusetts residents who are required to file but fail to do so. Indeed, at least six members of the Massachusetts legislature have failed to file tax returns in the last few years. ${ }^{22}$ 
The law will likely miss many temporarily uninsured people who file tax returns. It is important to realize that when we speak of 550,000 uninsured people in Massachusetts, or 46 million nationwide, we are merely speaking of a snapshot in time. That an individual is uninsured today does not mean that he or she was uninsured yesterday or will be uninsured tomorrow. In fact, most of the uninsured are uninsured for only a relatively brief period. For example, when workers lose their jobs they may lose their insurance, but they become insured again when they find new employment. Since the law allows people to go without insurance for up to 63 days (conceivably up to 126 days if the uninsured spell falls across two different tax years), the mandate will simply miss many of the temporarily uninsured.

During the program's first year, the penalty for failing to obtain insurance will be the loss of the individual's personal exemption from the state income tax. The following year, the real penalty kicks in, a fine equal to 50 percent of the cost of a standard insurance policy. That has the perverse effect of creating penalties that are large enough to be onerous but still smaller than the cost of purchasing insurance. Many currently uninsured individuals may, therefore, make the perfectly rational though not inexpensive decision to pay the fine and continue without insurance.

The result of all this is that the act is likely to fall far short of its goal of insuring every Massachusetts resident.

Although an individual mandate is unlikely to achieve universal coverage or significantly reduce health care costs, it crosses an important line, accepting the principle that it is the government's responsibility to ensure that every American has health insurance. In doing so, it opens the door to further widespread regulation of the health care industry and political interference in personal health care decisions. The result will be a slow but steady spiral downward toward a government-run health care system.

Whatever the initial minimum benefits package consists of, special interests repre- senting various health care providers and disease constituencies can certainly be expected to lobby for the inclusion of additional services or coverage under any mandated benefits package.

Public choice dynamics is such that providers (who would make money from the increased demand for their services) and disease constituencies (whose members naturally have an urgent desire for coverage of their illness or condition) will always have a strong incentive to lobby lawmakers for inclusion under any minimum benefits package. The public at large will likely be unaware of the debate or see resisting the small premium increase caused by any particular additional benefit as unworthy of any great effort. It is a simple case of concentrated benefits and diffuse costs.

As more benefits are added, the cost of the mandate will increase. That will place legislators in a very difficult position. If they increase subsidies to keep pace with the rising cost of the mandate, the cost of the program will explode. On the other hand, if they hold subsidies steady, the increased cost will be borne by consumers, who will have no choice but to continue purchasing the ever more expensive insurance. Since consumers will have little or no leverage over insurers (they will no longer be able to refuse to buy their products), they can eventually be expected to turn to the government for relief.

Attempts to scale back benefits would certainly meet political opposition from powerful constituencies and complaints about "cuts." The only other alternative would be for the government to intervene directly by capping premiums. Insurers unable to charge more for an increasingly expensive product can be expected to trim costs by cutting back on their reimbursement rates to hospitals and physicians. The result will ultimately be rationing, and lack of available health care goods and services.

One should always be careful of "slippery slope" arguments. Yet, in this case, we've already begun slipping. Governor Romney originally proposed a low-cost, no-frills policy with a high

Public choice
dynamics is such
that providers
and disease
constituencies
will always
have a strong
incentive to lobby
lawmakers for
inclusion under
any minimum
benefits package.

Public choice dynamics is such that providers and disease constituencies will always have a strong incentive to lobby lawmakers for inclusion under benefits package. 


\section{The expansion of subsidies will greatly increase the number of people dependent on government.}

deductible. However, by the time the legislature finished with the bill, the required insurance included all the state's 40 mandated benefits. Those mandates include treatment for alcoholism, blood lead poisoning, bone marrow transplants, breast reconstruction, cervical cancer/HPV screening, clinical trials, contraceptives, diabetic supplies, emergency services, hair prostheses, home health care, in vitro fertilization, mammograms, mastectomy, maternity care and maternity stays, mental health generally (in addition there is a requirement for mental health parity), newborn hearing screening, offlabel drug use, PKU/formula, prostate screening, rehabilitation services, and well-child care. The services of the following providers must also be covered: chiropractors, dentists, nurse anesthetists, nurse midwives, optometrists, podiatrists, professional counselors, psychiatric nurses, psychologists, social workers, and speech or hearing therapists. Insurance policies must also provide coverage of adopted children, handicapped dependents, and newborns. ${ }^{23}$

It is worth noting that lobbyists spent roughly $\$ 7.5$ million attempting to influence the design of the new Massachusetts plan. ${ }^{24}$ The money appears to have been well spent.

The individual mandate, therefore, should not be seen in a vacuum. It is more akin to the first in a series of dominoes. "If you want to go down the road of an individual mandate, it's necessary to reform the entire health insurance system to make sure healthy people can get affordable coverage and sick people are not priced out of the market," says Gail Shearer of Consumers Union. ${ }^{25}$ By distorting the health care marketplace, an individual mandate sets in place a cascading series of additional mandates and regulations resulting, ultimately, in a government-run health care system.

\section{The Subsidies}

The number-one reason that people give for not purchasing insurance is that they cannot afford it. ${ }^{26}$ Therefore, under the Massachusetts mandate that individuals buy insurance, low- and middle-income workers will have to receive some form of subsidy. The Massachusetts law provides for subsidies on a sliding scale for those with incomes up to 300 percent of the federal poverty level. ${ }^{27}$ That means subsidies will be available for those with incomes ranging from $\$ 30,480$ for a single individual to as much as $\$ 130,389$ for a married couple with seven children. ${ }^{28}$ A typical married couple with two children will qualify for a subsidy if their income is below $\$ 58,500$.

The subsidies under Governor Romney's plan for Massachusetts will cost about $\$ 725$ million per year, with other aspects of the program driving total costs to approximately $\$ 1.56$ billion. ${ }^{29}$ To some degree, savings from reduced uncompensated care payments will offset the new costs. ${ }^{30}$ On the other hand, increased coverage will almost certainly lead to increased usage, driving up overall health care costs and necessitating larger subsidies. A legislative analysis of the plan suggests that within two years the program will face a shortfall of at least $\$ 160$ million. ${ }^{31}$ Moreover, if the mandated benefits package increases as predicted above, there will be pressure to increase subsidies still further.

There are two significant dangers to subsidies of this magnitude. First, the expansion of subsidies will greatly increase the number of people dependent on government. Given that the median national income is $\$ 44,389$, the Massachusetts subsidies extend government welfare programs well into the middle class. As with all means-tested government programs, we can expect this new middle-class welfare benefit to discourage work, family formation, wealth accumulation, and self-sufficiency, as well as create a voting constituency for ever-expanding benefits.

Second, the subsidies are liable to squeeze out unsubsidized coverage, encouraging businesses to cease offering employer-provided plans, shifting the cost of insurance to taxpayers. That crowding-out phenomenon has been readily apparent with both traditional Medicaid and the State Children's Health Insurance Program. A Robert Wood Johnson Foundation survey of 22 studies of the relationship between government insurance pro- 
grams and private coverage concluded that substitution of government for private coverage "seems inevitable." 32 Other studies have shown that when government programs are cut back, private coverage increases. ${ }^{33}$

This last issue highlights yet another problem with Massachusetts subsidies-they are poorly targeted. Many of the people eligible for coverage already have health insurance. Therefore, the subsidies should be seen, not just as a method of increasing coverage, but as a way of shifting a large portion of insurance costs from individuals to the tax system. Subsidies become simply another form of income redistribution. While many taxpayers may accept such redistribution to the truly poor, how will they feel about financing transfers to the middle class?

\section{The Connector}

Although it has received less media attention than other aspects of the act, one of the most significant aspects of the law is the creation of the Massachusetts Health Care Connector to combine the current small group and individual markets under a single unified set of regulations. ${ }^{34}$ Supporters such as the Heritage Foundation consider the Connector the single most important change made by the law, calling it "the cornerstone of the new plan" and "a major innovation and a model for other states."35

Both the individual and the small group markets are highly regulated in Massachusetts, which makes them inefficient and leads to higher costs, especially in the individual market. The expectation is that combining the two and establishing a single regulatory system will make individual insurance more available and affordable. Supporters suggest that the price of individual insurance policies could initially decline by $25-40$ percent, though such projections remain untested. ${ }^{36}$

The Connector is also intended to allow individuals and workers in small companies to take advantage of the economies of scale, in terms of both administration and risk pooling, that are currently enjoyed by large employers. Multiple employers will be able to pay into the Connector on behalf of a single employee. And, most important, the Connector will allow workers to use pretax dollars to purchase individual insurance. This will make insurance personal and portable, rather than tied to an employer.

The Connector will not actually be an insurer. Insurance will still be provided by the private sector. Rather, the Connector will function as a clearinghouse, a sort of wholesaler or middleman, matching customers with providers and products. It will also allow small businesses and individuals to pool their resources to take advantage of the economies of scale available to large group plans.

Beginning in 2007, any individual living in Massachusetts can purchase an individual insurance policy through the Connector. In addition, any business with 50 or fewer employees can choose the Connector as its group health insurance plan. If it does, that company's workers will be able to choose from the array of plans offered through the Connector (subject to restrictions discussed below). Workers will be purchasing their insurance on an individual basis, meaning that they will be able to keep the coverage if they lose their jobs or take it with them if they change jobs. And, finally, beginning in July 2009, low-income individuals currently receiving health care through the state's public assistance programs will be shifted into the Connector.

There is considerable disagreement about what powers the Connector will have to regulate what insurance products can be sold. Some restrictions are specified. For example, the maximum deductible allowed is $\$ 2,700$ for an individual and $\$ 5,450$ for a family. While this conforms to current federal law, it locks in the status quo at a time when there are attempts to change federal restrictions on health savings accounts (HSAs). Moreover, individuals choosing a high deductible policy must combine it with an HSA. As mentioned above, policies must comply with the state's mandated benefits (with the exception noted below). They must also comply with the

\section{One of the} most significant aspects of the law is the creation of the Massachusetts Health Care Connector to combine the current small group and individual markets under a single unified set of regulations. 


\section{The Connector} is essentially a form of managed competition with insurance provided by the private sector but within an artificial government-designed and governmentcontrolled marketplace. state's community rating requirements, and there are other restrictions designed to limit the ability of insurers to segment the market according to risk. ${ }^{37}$

Except for these restrictions, defenders of the Massachusetts law say that the Connector has no authority to regulate insurance and must offer for sale any and all products that have been approved for sale by the state insurance commissioner. "The Connector will neither design the insurance products being offered nor regulate the insurers offering the plans. Insurers will continue to be regulated by the state's Division of Insurance and will be free to design and price the plans they offer through the Connector, subject to the provisions of Massachusetts' existing insurance law," writes Ed Haislmaier of the Heritage Foundation. ${ }^{38}$ However, others, including many providers and insurers, take a different view. "The Connector has a fair amount of discretion to develop its plans for affordable products," according to the Massachusetts Hospital Association. ${ }^{39}$ A conference committee report accompanying the bill says that plans "must be approved by the Connector." ${ }^{, 4}$

The actual language of the law is vague, and it certainly provides reason for concern. The Connector is authorized to offer a "connector seal of approval" to products that provide "high quality and good value." The Connector itself is left to define what constitutes high quality and good value, but it is significant that that phrase frequently appears in the legislation as justification for mandated benefits. The law is silent on whether products that do not receive the seal of approval can be sold through the Connector or, if so, on what terms. ${ }^{41}$ However, an analysis of the legislation by the law firm of Ropes \& Grey suggests that the Connector could limit products to those receiving the seal of approval. ${ }^{42}$

Regardless of what products the Connector can theoretically offer, many people who buy insurance through it will find their choices severely constrained. That is because anyone who receives any subsidy is limited to a choice among a more limited menu of insurance options that have low deductibles and limited cost sharing. ${ }^{43}$ Since 56 percent of the uninsured in Massachusetts have incomes under 300 percent of the federal poverty level, more than half of those using the Connector will fall under this restriction. For those earning under the poverty level itself, plans can have neither a deductible nor any cost sharing or copayments.

Under the law, health insurance in Massachusetts will have two tiers. Individuals under 300 percent of the poverty level will be locked into what resembles a "Medicaid plus" type of program, a privately provided, heavily subsidized and regulated insurance plan. Those with incomes above 300 percent of poverty will have more, but still limited, choices.

The law does include a provision allowing workers aged 19 through 26 to purchase lowcost, specially designed products offered through the Connector. Those products may avoid many of the state's mandated benefits (although some of the most expensive mandates, including mental health benefits and prescription drug coverage will still be required). ${ }^{44}$ However, it is uncertain how this provision interrelates with the requirement that all subsidized individuals must choose from the more limited array of comprehensive plans. Since presumably most young people will be eligible for subsidies, it may be that very few will be able to take advantage of these policies. For that matter, if the more comprehensive policies are subsidized, it is not clear why anyone would want to.

There is no prohibition on selling small group or individual insurance outside the Connector. However, because the subsidies and tax advantages are available only within the Connector, and because of its competitive advantage in terms of pooling costs and risk, the Connector will eventually squeeze out any outside market. In the end, the Connector will become a monopsony purchaser of health insurance similar to the community purchasing pools envisioned under the Clinton health care plan of 1993.

The Connector is essentially a form of managed competition with insurance provided by the private sector but within an arti- 
ficial government-designed and governmentcontrolled marketplace. Supporters of managed competition are critical of a health insurance marketplace that they see as "fragmented" and "Balkanized"; the Heritage Foundation argues, "Markets sometimes work more efficiently and effectively when there is a single place to facilitate diverse economic activity." 45

Supporters of the Connector offer two analogies, one of which is somewhat inaccurate and the other quite telling. Ed Haislmaier, for example, likens the Connector to CarMax. "There are many different kinds of cars to choose from, all offered through one giant dealership. ${ }^{\text {} 6}$ However, CarMax is not the only dealership. If you don't like what CarMax has to offer, you can shop on Vehix.com, visit local dealerships, or simply choose not to buy a car. No such options will be available under the Connector. As discussed above, there is likely to be little or no individual or small group market outside the Connector. And individuals are required to purchase insurance under the individual mandate.

A more apt analogy is the Federal Employee Health Benefit Program as suggested by Bob Moffit and Nina Owcharenko, also of the Heritage Foundation. ${ }^{47}$ (The Heritage Foundation has promoted the FEHBP as a model for health care reform at least since 1993.) Like the FEHBP, the Connector exemplifies the basic features of managed competition. First, consumers can choose from a limited menu of competing insurance plans. Subsidies are structured so that consumers choosing more expensive plans have to bear a portion of the cost. And most important, insurers are prohibited from competing on the basis of their ability to price and manage risk. That is, plans must accept all applicants and charge everyone the same price regardless of individual health risk. $^{48}$

Because Massachusetts insurers will not be able to adjust their premiums on the basis of age, sex, current health, or other risk factors, they will compete on a very constrained basis. There is some limited price competition, but since plans cannot reduce costs by managing risks, and their ability to reduce cost through benefit design is also limited, such competition can occur only at the margins. This is particularly problematic since inability to price according to risk generally causes insurers to retreat toward the mean. That results in an overprovision of services to the healthy and an underprovision to the sick.

Managed competition is an attempt to be a little bit pregnant on the question of markets versus government control. Or, as University of Chicago law professor Richard Epstein says, managed competition is "an oxymoron. One can either have managed health care or competition in health care services. It is not possible to have both simultaneously., ${ }^{, 9}$

\section{Employer Mandates}

The law imposes several new requirements on businesses. First, all businesses with more than 10 employees that do not provide workers with health insurance must pay a fee of up to $\$ 295$ per employee per year. ${ }^{50}$ The actual fee will be determined later and is designed to roughly mimic the impact of the uncompensated care surcharge on insurance plans. Governor Romney vetoed this provision using his line item veto authority, but the veto was overridden by the legislature. Most observers believe that employer taxes generally reduce wages or jobs, or both. Still, as such "play or pay" mandates go, the levy is relatively modest. The bigger danger is that it sets up a potential stream of additional revenue for funding the growing cost of the program's subsidies. With current funding expected to be short of what is required within a few years, there will be a strong legislative temptation to see businesses as a potential funding source.

An additional penalty is imposed on employers whose workers repeatedly receive uncompensated care. If a company's employees incur at least $\$ 50,000$ in uncompensated care, the company may be charged a "free-rider fee" of up to 100 percent of the cost of the care in excess of $\$ 50,000 .^{51}$ This is potentially a much more significant penalty. However,

\section{Managed competition is an attempt to be a little bit pregnant on the question of markets versus government control.}


companies can avoid this penalty if they offer their employees a Section 125 plan.

And, finally, all employers with 10 or more employees are required to offer their employees a Section 125 plan. $^{52}$ These are cafeteria plans, authorized under Section 125 of the federal Internal Revenue Code, that allow employees to set aside pretax dollars toward payment of insurance premiums, medical care, and dependent care expenses. In many ways they are similar to HSAs except that account balances cannot be carried over from year to year. Companies are required to offer the plans but not to make contributions to them.

\section{More Bureaucracy}

Although not a central component of the reform, it is worth noting that the Massachusetts law greatly expands the state's health care bureaucracy, creating at least 10 new boards, commissions, and other institutions.

For example, the law establishes a Health Care Cost and Quality Council to promote "high quality, safe, effective, timely, efficient, equitable, culturally competent, and patientcentered health care. ${ }^{, 53}$ This new agency will "develop goals that are intended to lower or contain the growth in health care costs while improving the quality of care." ${ }^{54}$ If there was ever a more permanent and open-ended charter, it is hard to think of it. But if that is not enough to keep it busy, the council is also charge with eliminating "racial and ethnic health disparities. ${ }^{, 55}$

And, just in case the council fails to eliminate those disparities, the law also creates a Health Disparities Council to address the issue. There is also a Health Payment Policy Advisory Board, a Public Health Council, a Health Access Bureau, a Health Safety Net Office, and, in a bit of hindsight, a commission to study the merger of the group and nongroup markets mandated by the law. ${ }^{56}$

One wonders why "market-based" health care reform needs so much more government.

\section{Conclusion}

Massachusetts's reforms are an attempt to address some legitimate concerns. The freerider problem of uncompensated care is a real issue, though much smaller than proponents of reform assume. A fragmented regulatory environment has added to costs in both the small group and individual insurance markets. And federal tax policy locks workers into employer-provided health insurance, instead of allowing them to purchase personal and portable individual insurance. Governor Romney and the Massachusetts legislature deserve credit for trying to deal with those issues.

The law also contains a few good ideas. For example, it provides for state tax deductibility of HSAs. It also allows health maintenance organizations to offer HSAs. ${ }^{57}$ Previously, only preferred provider organizations and fee-forservice plans could do so. The law also exempts policies sold through the Connector from the state's "any willing provider" requirements. ${ }^{58}$

However, in general, the law takes us in the wrong direction. If the goal is universal coverage, this law won't get us there. But its individual mandate does open the door to widespread regulation of the health care industry and political interference in personal health care decisions. If the goal is to subsidize coverage for people who can't afford it, this is a remarkably inefficient approach. The subsidized will include many people who are already paying for their own insurance. The subsidies will encourage businesses to drop coverage they currently provide, shifting costs to the taxpayer. And the subsidies will increase dependence on government for thousands of middle-class citizens. Moreover, the law imposes new burdens on business and creates a host of new government bureaucracies to manage the health care system.

Most important, the law heads down the road toward managed competition. In that way it resembles the Clinton health care plan. Rather than true free-market reform, the law 
creates an artificial marketplace that will ultimately restrict consumer choice and freedom. Whatever the benign intent of the law's proponents, the Connector puts in place power to severely regulate and restrict the insurance marketplace. What health care needs is more consumer control and a freer market, not more "management."

Several states, including California, Louisiana, Maryland, and Wisconsin, as well as the District of Columbia are reportedly considering legislation similar to the Massachusetts law. Governor Romney and others suggest that it could serve as a model for the nation. "If we did it there, we can do it in other states," Romney said in a speech to the U.S. Chamber of Commerce. ${ }^{59}$ The Heritage Foundation has announced that it is undertaking a campaign to sell the concept to other states. ${ }^{60}$

One of the advantages of our federalist system is that states are able to act as "laboratories of democracy." With time, we may see how the Massachusetts experiment turns out. Until then, there is ample reason for states and the federal government not to follow its lead.

\section{Notes}

1. Massachusetts, Chapter 58 of the Acts of 2006, Section 12.

2. Ibid., Section 13.

3. Ibid., Section 45.

4. Ibid., Section 101.

5. Ibid., Section 47.

6. Ibid., Section 45(b).

7. Edmund F. Haislmaier, "Mitt's Fit," National Review Online, January 27, 2006.

8. Ron Fournier, "Clinton Praises Romney Health Care Plan,” Associated Press, April 5, 2006.

9. Heidi Przybyla, "Romney Targets Democrats' Turf on Health and Education for 2008," Bloomberg, March 30, 2006.

10. Congressional Budget Office, "The Budgetary Treatment of an Individual Mandate to Buy
Health Insurance,” Memorandum, August 1994.

11. Massachusetts Legislature, "Health Care Access and Affordability," Conference Committee Report, April 3, 2006, p. 3, http://www.mass.gov/ legis/summary.pdf.

12. Lynda Flowers et al., Reforming the Health Care System: State Profiles (Washington: AARP, 2006), pp. 96-99.

13. Sharon Silow-Carroll and Tanya Alteras, "Stretching State Universal Health Care Dollars: Innovative Uses of Uncompensated Care Funds," Commonwealth Fund, October 2004.

14. http://www.cms.hhs.gov/NationalHealthEx pendData/05_NationalHealthAccountsStateHea lthAccounts.asp\#TopOfPage.

15.Jack Hadley and John Holahan, "The Cost of Care for the Uninsured: What Do We Spend, Who Pays, and What Would Full Coverage Add to Medical Spending?" Kaiser Commission on Medicaid and the Uninsured, May 10, 2004.

16. See Greg Scandlen, "The Pitfalls of Mandating Health Insurance," Council for Affordable Health Insurance Issues \& Answers no. 135, April 2006.

17. http://www.iii.org/media/hottopics/insurance /compulsory/.

18. Insurance Research Council, "Uninsured Motorists, 2000 Edition,” December 2000.

19. Stephanie Jones, "Uninsured Drivers Travel under the Radar," Insurance Journal, August 18, 2003.

20. Massachusetts, Chapter 58 of the Acts of 2006, Sections 12 (b), 13.

21. "Proposed Health Reform in Massachusetts: Net Gain for Business Community," Families USA Foundation, Washington, January 2006, p. 7.

22. David R. Guarino, "Six House Reps Fail to File Income Tax Returns," Boston Herald, March 10, 2005.

23. Victoria Craig Bunce, J. P. Wieske, and Vlasta Prikazky, "Health Insurance Mandates in the States, 2006," Council for Affordable Health Insurance, March 2006.

24. Scott Helman, "Lobbyists Took in $\$ 7.5$ Million on Health Bill," Boston Globe, April 5, 2006.

25. Quoted in Julie Appleby, "Mass. Gov. Romney's Health Care Plan Says Everyone Pays," USA Today, July 4, 2005.

26. "The Uninsured: A Primer, Key Facts about 
Americans without Health Insurance," Kaiser Family Foundation, December 2003.

27. Massachusetts, Chapter 58 of the Acts of 2006, Section 45.

28. Bridgett Wagner of the Heritage Foundation, letter to Grace Marie Turner of the Galen Institute, May 5, 2006, citing a response from Ed Haislmaier to an op-ed by Betsy McCaughey in the Wall Street Journal.

29. Scott Helman and Liz Kowalczyk, "Joy, Worries on Health Care," Boston Globe, April 13, 2006.

30. Massachusetts also expects to receive approximately $\$ 310$ million annually in federal funds under a Medicaid waiver.

31. Massachusetts Legislature. Even these estimates may be based on unrealistic assumptions. For example, medical inflation in Massachusetts has been running between 10 and 14 percent annually. The act's projected costs are based on a medical inflation rate of 10 percent. Higher inflation would drive subsidy costs to more than $\$ 800$ million per year. Lawmakers also assumed that use of the state's "free care pool," a pot of money used to pay hospitals for treating uninsured residents, will drop dramatically as more uninsured residents buy insurance. The savings are to go toward subsidies to help low-income uninsured residents buy health plans. But if, for reasons discussed above, the mandate fails to significantly reduce the number of uninsured, the savings will be less than projected. Helman and Kowalczyk.

32. Getsur Davidson et al., "Public Program CrowdOut of Private Coverage: What Are the Issues?" Robert Wood Johnson Foundation Research Synthesis Report no. 5, June 2004.

33. George Borjas, "Welfare Reform, Labor Supply, and Health Insurance in the Immigrant Population," Journal of Health Economics 22 (2003): 956-57.

34. Massachusetts, Chapter 58 of the Acts of 2006, Section 101. The law defines the Connector as "a body politic and corporate and a public instrumentality." It is designed to operate independent of any other government agency and has a corporate charter, but its board consists of the Massachusetts secretary of administration and finance, the state Medicaid director, the state commissioner of insurance, the executive director of the group insurance commission, three members appointed by the governor, and three members appointed by the attorney general. As an entity it falls somewhere between a government agency and a private corporation. One useful analogy would be the Federal Reserve Board.

35. Robert Moffit and Nina Owcharenko, "Under- standing Key Parts of the Massachusetts Health Plan," Heritage Foundation WebMemo no. 1045. April 20, 2006.

36. Massachusetts Office of the Governor, "Massachusetts Healthcare Reform," PowerPoint presentation, April 10, 2006.

37. Massachusetts, Chapter 58 of the Acts of 2006, Sections 101, 76.

38. Edmund Haislmaier, "The Significance of Massachusetts Health Reform," Heritage Foundation WebMemo no. 1035, April 11, 2006.

39. "Summary of Massachusetts Health Care Reform Compromise Bill,” Massachusetts Hospital Association, April 4, 2006.

40. Massachusetts Legislature, p. 3.

41. Massachusetts, Chapter 58 of the Acts of 2006, Section 101.

42. Harvey Cotton et al., "Massachusetts Health Care Reform Legislation: Chapter 58 of the Acts of 2006, An Act Promoting Access to Affordable, Quality, Accountable Health Care," Ropes \& Grey, April 17, 2006, p. 2.

43. Massachusetts Office of the Governor, "An Act Promoting Access to Affordable, Quality, Accountable Health Care: Summary of Key Features," May 9, 2006.

44. Massachusetts, Chapter 58 of the Acts of 2006, Section 90. The actual design of these plans is left to the Connector.

45. Haislmaier, "The Significance of Massachusetts Health Reform."

46. Ibid.

47. Moffit and Owcharenko.

48. For a discussion of the defining components of managed competition, see Alain Enthoven, "The History and Principles of Managed Competition," Health Affairs, supplement (1993).

49. Richard Epstein, "Unmanageable Care," Reason, May 1993.

50. Massachusetts, Chapter 58 of the Acts of 2006, Section 47.

51. Ibid., Section 45 (b).

52. Ibid., Section 48.

53. Ibid., Section 16(K). 
54. Ibid., Section 16(L)(a).

55. Ibid., Section 16(L)(a)

56. Ibid., Sections 3, 114.

57. Ibid., Section 60.
58. Ibid., Section 101.

59. Quoted in Sean Higgins, "Massachusetts Health Care Law Could Be Model for the Nation," Investor's Business Daily, May 2, 2006.

60. Ibid. 


\section{OTHER STUDIES IN THE BRIEFING PAPERS SERIES}

96. Free Speech and the $\mathbf{5 2 7}$ Prohibition by Stephen M. Hoersting (April 3, 2006)

95. Dispelling the Myths: The Truth about TABOR and Referendum $\mathrm{C}$ by Michael J. New and Stephen Slivinski (October 24, 2005)

94. The Security Pretext: An Examination of the Growth of Federal Police Agencies by Melanie Scarborough (June 29, 2005)

93. Keep the Cap: Why a Tax Increase Will Not Save Social Security by Michael Tanner (June 8, 2005)

92. A Better Deal at Half the Cost: SSA Scoring of the Cato Social Security Reform Plan by Michael Tanner (April 26, 2005)

91. Medicare Prescription Drugs: Medical Necessity Meets Fiscal Insanity by Joseph Antos and Jagadeesh Gokhale (February 9, 2005)

90. Hydrogen's Empty Environmental Promise by Donald Anthrop (December 7, 2004)

89. Caught Stealing: Debunking the Economic Case for D.C. Baseball by Dennis Coates and Brad R. Humphreys (October 27, 2004)

88. Show Me the Money! Dividend Payouts after the Bush Tax Cut by Stephen Moore and Phil Kerpen (October 11, 2004)

87. The Republican Spending Explosion by Veronique de Rugy (March 3, 2004)

86. School Choice in the District of Columbia: Saving Taxpayers Money, Increasing Opportunities for Children by Casey J. Lartigue Jr. (September 19, 2003)

85. Smallpox and Bioterrorism: Why the Plan to Protect the Nation Is Stalled and What to Do by William J. Bicknell, M.D., and Kenneth D. Bloem (September 5, 2003)

84. The Benefits of Campaign Spending by John J. Coleman (September 4, 2003)

83. Proposition 13 and State Budget Limitations: Past Successes and Future Options by Michael J. New (June 19, 2003)

82. Failing by a Wide Margin: Methods and Findings in the 2003 Social Security Trustees Report by Andrew G. Biggs (April 22, 2003)

81. Lessons from Florida: School Choice Gives Increased Opportunities to Children with Special Needs by David F. Salisbury (March 20, 2003)

80. States Face Fiscal Crunch after 1990s Spending Surge by Chris Edwards, Stephen Moore, and Phil Kerpen (February 12, 2003) 
79. Is America Exporting Misguided Telecommunications Policy? The U.S.-Japan Telecom Trade Negotiations and Beyond by Motohiro Tuschiya and Adam Thierer (January 7, 2003)

78. This Is Reform? Predicting the Impact of the New Campaign Financing Regulations by Patrick Basham (November 20, 2002)

77. Corporate Accounting: Congress and FASB Ignore Business Realities by T. J. Rodgers (October 25, 2002)

76. Fat Cats and Thin Kittens: Are People Who Make Large Campaign Contributions Different? by John McAdams and John C. Green (September 25, 2002)

75. 10 Reasons to Oppose Virginia Sales Tax Increases by Chris Edwards and Peter Ferrara (September 18, 2002)

74. Personal Accounts in a Down Market: How Recent Stock Market Declines Affect the Social Security Reform Debate by Andrew Biggs (September 10, 2002)

73. Campaign Finance Regulation: Lessons from Washington State by Michael J. New (September 5, 2002)

72. Did Enron Pillage California? by Jerry Taylor and Peter VanDoren (August 22, 2002)

71. Caught in the Seamless Web: Does the Internet's Global Reach Justify Less Freedom of Speech? by Robert Corn-Revere (July 24, 2002)

70. Farm Subsidies at Record Levels As Congress Considers New Farm Bill by Chris Edwards and Tad De Haven (October 18, 2001)

69. Watching You: Systematic Federal Surveillance of Ordinary Americans by Charlotte Twight (October 17, 2001)

68. The Failed Critique of Personal Accounts by Peter Ferrara (October 8, 2001)

67. Lessons from Vermont: 32-Year-Old Voucher Program Rebuts Critics by Libby Sternberg (September 10, 2001)

66. Lessons from Maine: Education Vouchers for Students since $\mathbf{1 8 7 3}$ by Frank Heller (September 10, 2001)

65. Internet Privacy and Self-Regulation: Lessons from the Porn Wars by Tom W. Bell (August 9, 2001)

64. It's the Spending, Stupid! Understanding Campaign Finance in the BigGovernment Era by Patrick Basham (July 18, 2001) 
63. A 10-Point Agenda for Comprehensive Telecom Reform by Adam D. Thierer (May 8, 2001)

62. Corrupting Charity: Why Government Should Not Fund Faith-Based Charities by Michael Tanner (March 22, 2001)

61. Disparate Impact: Social Security and African Americans by Michael Tanner (February 5, 2001)

60. Public Opinion and Campaign Finance: A Skeptical Look at Senator McCain's Claims by David M. Primo (January 31, 2001)

59. Lessons of Election 2000 by John Samples, Tom G. Palmer, and Patrick Basham (January 2, 2001)

58. Will the Net Turn Car Dealers into Dinosaurs? State Limits on Auto Sales Online by Solveig Singleton (July 25, 2000)

57. Legislative Malpractice: Misdiagnosing Patients' Rights by Greg Scandlen (April 7, 2000)

56. "We Own the Night": Amadou Diallo's Deadly Encounter with New York City's Street Crimes Unit by Timothy Lynch (March 31, 2000)

55. The Archer-Shaw Social Security Plan: Laying the Groundwork for Another S\&L Crisis by Andrew G. Biggs (February 16, 2000)

54. Nameless in Cyberspace: Anonymity on the Internet by Jonathan D. Wallace (December 8, 1999)

53. The Case against a Tennessee Income Tax by Stephen Moore and Richard Vedder (November 1, 1999)

52. Too Big to Fail? Long-Term Capital Management and the Federal Reserve by Kevin Dowd (September 23, 1999)

51. Strong Cryptography: The Global Tide of Change by Arnold G. Reinhold (September 17, 1999)

50. Warrior Cops: The Ominous Growth of Paramilitarism in American Police Departments by Diane Cecilia Weber (August 26, 1999)

49. Mr. Smith, Welcome to Washington by Roger Pilon (July 30, 1999)

Published by the Cato Institute, Cato Briefing Papers is a regular series evaluating government policies and offering proposals for reform. Nothing in Cato Briefing Papers should be construed as necessarily reflecting the views of the Cato Institute or as an attempt to aid or hinder the passage of any bill before Congress.
Contact the Cato Institute for reprint permission. Additional copies of Cato Briefing Papers are $\$ 2.00$ each ( $\$ 1.00$ in bulk). To order, or for a complete listing of available studies, write the Cato Institute, 1000 Massachusetts Avenue, N.W., Washington, D.C. 20001. (202) 842-0200 FAX (202) 842-3490. 